\title{
Complementation of Repair Gene Mutations on the Hemizygous Chromosome 9 in CHO: A Third Repair Gene on Human Chromosome 19
}

\author{
Larry H. Thompson, * Linda L. Bachinski, † Raymond L. Stallings, $\ddagger$ Gaudenz Dolf, $\nmid{ }^{\prime}$ \\ Christine A. Weber,* Andries Westerveld, $\S$ and Michael J. Siciliano $†$ \\ *Biomedical Sciences Division, Lawrence Livermore National Laboratory, Livermore, California 94550; †Department of Molecular \\ Genetics, The University of Texas M. D. Anderson Cancer Center, Houston, Texas 77030; łGenetics Group, Los Alamos \\ National Laboratory, Los Alamos, New Mexico 87545; and §Department of Human Genetics, \\ Academic Medical Center, 1105 AZ Amsterdam, The Netherlands \\ Received February 17, 1989; revised June 12, 1989
}

\begin{abstract}
A human DNA repair gene, ERCC2 (Excision Repair Cross Complementing 2), was assigned to human chromosome 19 using hybrid clone panels in two different procedures. One set of cell hybrids was constructed by selecting for functional complementation of the DNA repair defect in mutant CHO UV5 after fusion with human lymphocytes. In the second analysis, DNAs from an independent hybrid panel were digested with restriction enzymes and analyzed by Southern blot hybridization using DNA probes for the three DNA repair genes that are located on human chromosome 19: ERCC1, ERCC2, and $X$-Ray Repair Cross Complementing 1 (XRCC1). The results from hybrids retaining different portions of this chromosome showed that $E R C C 2$ is distal to XRCC1 and in the same region of the chromosome 19 long arm (q13.2-q13.3) as ERCC1, but on different $M l u I$ macrorestriction fragments. Similar experiments using a hybrid clone panel containing segregating Chinese hamster chromosomes revealed the hamster homologs of the three repair genes to be part of a highly conserved linkage group on Chinese hamster chromosome number 9. The known hemizygosity of hamster chromosome 9 in $\mathrm{CHO}$ cells can account for the high frequency at which genetically recessive mutations are recovered in these three genes in CHO cells. Thus, the conservation of linkage of the repair genes explains the seemingly disproportionate number of repair genes identified on human chromosome 19. 1989 Acudemic Press, Inc.
\end{abstract}

\section{INTRODUCTION}

A number of recessive DNA repair mutants have been isolated from Chinese hamster $\mathrm{CHO}$ and V79 cell

\footnotetext{
${ }^{1}$ Present address: Institut fur Tierzucht, Vet. Med. Fak., der Universtaet Bern, 3012 Bern, Switzerland.
}

lines (Thompson, 1985; Collins and Johnson, 1987; 7dzienicka and Simons, 1987; Hickson and Harris, 1988). Generally, mutants are of two types: those defective in nucleotide excision repair, which are hypersensitive to ultraviolet light (UVL) and large-adduct chemicals, and those defective in other repair functions rendering them sensitive to a wide variety of DNA damaging agents (such as X-or $\gamma$-rays, bleomycin, and methylating agents). Eight genetic complementation groups have been described for UVL-sensitive mutants of rodent origin (Thompson et al., 1988) and six groups for ionizing-radiation-sensitive Chinese hamster mutants (Jones et al., 1988).

Human DNA repair genes have been identified by their ability to correct the defects in these rodent mutants. Originally, these genes were named for that spe cific ability, e.g., Excision or X-Ray Repair Complementing Defective Repair in the Chinese Hamster 1 (ERCC1 or XRCC1), with the number indicating the chronological order in which the gene was identified. Since the same human genes have subsequently been shown to complement defects in homologous loci of mouse mutant lines as well as hamster (Thompson et al., 1987), the nomenclature has been broadened, while keeping the same alphabetic symbols, to Excision or $X$-Ray Repair Cross Complementing. A further change in the nomenclature system has been to number the genes according to the complementation group assigned to the rodent mutant used to identify the human gene (Thompson and Bootsma, 1988). To accommodate this, CHO UVL complementation groups 1 and 2 were switched to agree with the gene names as published.

Concordant segregation of the human chromosomes with the repair phenotype from hybrids made between human cells and CHO mutant UV2O (now representing UVL complementation group 1) allowed the chromosomal assignment of ERCC1 to human chromosome 
19 (Thompson et al., 1985). Similarly, methods with mutants representing other complementation groups have allowed the assignments of the human genes for XRCC1 (Siciliano et al., 1986a), ERCC3, and ERCC5 (Thompson et al., 1987) to human chromosomes 19, 2, and 13 , respectively.

Here, we present the chromosomal assignment of a third repair gene, ERCC2, to human chromosome 19 by identification of the correcting human chromosome in hybrids made with CHO mutant UV5, formerly in UVL complementation group 1 (Thompson et al., 1981) which is now redesignated complementation group 2 . We also regionally assign all three chromosome 19 DNA repair genes within the linear order of markers for the long arm of the chromosome using their DNAs to probe a panel of hybrids informative for different regions of chromosome 19 , and add to the data suggesting that all three genes are distinct physical entities. Cross-hybridization of the human cDNAs for the repair genes to Chinese hamster DNA on a hybrid clone panel informative for hamster chromosomes enabled us to determine the evolutionary conservation of the linkage group, chromosomal assignments of these loci in the Chinese hamster, and the genetic consequences of those assignments on the frequency of mutations at these loci in CHO cells.

\section{MATERIALS AND METHODS}

\section{Isolation of Hybrids of UVS}

For making hybrids of UV5, we used a thioguanineresistant $\left(\mathrm{TG}^{\mathrm{r}}\right)$, hypoxanthine phosphoribosyltransferase (HPRT)-deficient clone of UV5 so that hybrids could be selected on the basis of complementation of both HPRT and DNA repair functions. This approach minimized the chance of recovering repair-proficient revertants. To each of 10 dishes containing $1 \times 10^{6}$ UV5-TGr cells were added $5 \times 10^{6}$ of human lymphocytes. Following incubation for $4 \mathrm{~h}$ medium was slowly removed by aspiration, and serum-free medium containing $47 \%$ polyethylene glycol $1000+10 \%$ dimethyl sulfoxide (DMSO) was added for $60 \mathrm{~s}$. Cells were rinsed three times with medium containing $10 \%$ DMSO. After a 24-h incubation, the cells from each dish were counted and replated into two 100-mm dishes and one 24-well tray containing HAT medium (hypoxanthine/amethopterin/thymidine) and decarbamoyl mitomycin $\mathrm{C}$ (dcMMC; obtained from A. Carrano, Lawrence Livermore National Laboratory) at $120 \mathrm{nM}$. UV5 cells had been found to be approximately eightfold hypersensitive to this nonfunctional derivative of mitomycin $\mathrm{C}$ (Hoy et al., 1984). After 4 days under double selection, the medium was replaced with medium containing 60 $\mathrm{n} M \mathrm{dc} M \mathrm{MC}$ and thymidine + hypoxanthine. Colonies were isolated with Pipetman tips or rubber O-rings coated with silicon grease. Several days before freezing, the cultures were exposed again to $60 \mathrm{nM}$ dcMMC to eliminate possible sensitive segregants. Four additional hybrid clones were isolated in parallel by repeated exposure to $3 \mathrm{~J} / \mathrm{m}^{2}$ of UVL under the conditions described for hybrids of UV135 (Thompson et al., 1987).

\section{Isolation of Hybrid Subclones}

Subclones in which UVL resistance had been lost due to segregation of the complementing human chromosome were isolated. This was accomplished by growing primary hybrids in the absence of dcMMC for periods of 3 to 7 weeks before isolating subclones. Subcloning was done in 96 -well trays. Single colonies were isolated, tested for resistance to 3 or $4 \mathrm{~J} / \mathrm{m}^{2}$ of UVL radiation or to dcMMC, and grown to mass culture. Both sensitive and resistant subclones were obtained for three independent hybrids.

\section{Marker Characterization of Hybrids for Human Chromosomal Content}

'The presence or absence of human chromosomes in hybrid clones and subclones was first determined by a combination of isozyme and Southern blot analyses of chromosomally assigned biochemical and molecular markers as previously described (Siciliano and White, 1987; Thompson et al., 1987).

\section{Biotinylated Probe Cytogenetic Analysis}

Cytogenetic analysis of the hybrid cell line 5HL9-4 and subclone 20XP3542-1-4 was performed using biotinylated total human DNA as a probe for in situ hybridization. The details of the procedure were as originally described by Pinkel et al. (1986). In general, RNase-treated metaphase spreads were hybridized with biotinylated (by nick translation) total human HeLa cell sonicated DNA. Sites of hybridization were visualized under fluorescence microscopy following staining with fluorescein-avidin.

\section{UVL Survival Curves}

Cloning efficiencies following various doses of UVI, were determined for the $\mathrm{CHO}$ nucleotide excision repair complementation group 2 mutant (UV5), the wild-type CHO cell line from which it was derived (AA8), and a series of UVL-sensitive and -resistant hybrid clones and subclones. Procedures were those routinely used in this laboratory and described most recently in Thompson et al. (1987).

\section{Plasmid Extraction and Probe Preparation}

Probes for the following genes were used to determine the presence or absence of various chromosome 19 markers: pC3.59, a cDNA for Complement Component 3 (C3, Yamaoka et al., 1985); pHP450(1), a cDNA 
for Phenobarbitol-Inducible Cytochrome p450 (CYP2A, Davis et al., 1985; Phillips et al., 1985); pCII-711, a cDNA for Apolipoprotein C2 (APOC2, Jackson et al., 1984); pHMCK1, a cDNA for Creatine Kinase Muscle Form (CKMM, Perryman et al., 1986); pBR322cBHCG, a cDNA for Beta Chorionic Gonadotropin (CGB, Fiddes and Goodman, 1980); pcD4A4, a 3'-untranslated probe (Westerveld et al., 1984), and $\mathrm{pE} 12-$ 12, a cDNA probe (van Duin et al., 1986) for ERCC1; pKER2, a 3'-untranslated probe (Weber et al., 1988), and pER2-6, a cDNA (Weber, in preparation) for ERCC2; and pXR1-30, a cDNA for XRCC1 (Thompson et al., in preparation).

Plasmid preparation, probe excision, and squeeze freeze isolation were conducted according to standard techniques (Maniatis et al., 1982; Smith, 1980). Approximately $25 \mathrm{ng}$ was used for each labeling reaction. DNA was labeled with $\left[{ }^{32} \mathrm{P}\right] \mathrm{dCTP}$ to a specific activity of approximately $10^{9} \mathrm{cpm} / \mu \mathrm{g}$ DNA using a multiprime random priming kit from Amersham Corp. (Arlington Heights, IL).

\section{Hybrid Clone Mapping Panels}

Hybrid clone mapping panels, informative for identifying chromosomal assignments in the human genome and for the specific locations on chromosome 19 of sequences that hybridize to DNA probes, have been characterized and described by Stallings et al. (1988). Another panel informative for the chromosomal assignments of genes in the Chinese hamster genome has been assembled from material and data reported in a series of manuscripts and summarized in Siciliano et al. (1985).

\section{Field-Inversion Electrophoresis}

Cultured cells were trypsinized, counted, rinsed in $\mathrm{SE}$ buffer (75 $\mathrm{mM} \mathrm{NaCl}, 25 \mathrm{mM}$ EDTA, pH 7.4), and cast as plugs in 0.5\% "InCert" agarose (AMC Bioproducts, Rockland, ME) at $10^{6}$ cells per $100-\mu \mathrm{l}$ plug. Plugs were processed to extract DNA in situ (in place in the plugs) according to published procedures (Carle et al., 1986). After several rinses in TE buffer and equilibration for $30 \mathrm{~min}$ in $1 \times$ restriction enzyme reaction buffer (as described by the supplier), the plugs were covered with $100 \mu \mathrm{l}$ fresh buffer. Spermidine was added to $2 \mathrm{mM}$, DTT to $0.5 \mathrm{mM}$, and BSA to $0.1 \%$. Digestion of plug DNA was carried out at $37^{\circ} \mathrm{C}$ for 6 h using 40 units of $M l u \mathrm{I}$ (Boehringer-Mannheim, Indianapolis, IN). The restriction enzyme was then removed by digestion for $2 \mathrm{~h}$ at $56^{\circ} \mathrm{C}$ in $200 \mu \mathrm{l} \operatorname{ESP}(1 \%$ $N$-laurylsarcosine, $0.5 M$ EDTA, $1 \%$ proteinase $\mathrm{K}$, pH 9.0).

Approximately $\frac{1}{4}$ plug was loaded into each $1 \times 6$ $\mathrm{mm}$ slot of a $25 \times 20-\mathrm{cm}^{2} 1 \%$ agarose gel (Seakem) and field-inversion gel electrophoresis (FIGE) was carried out at $150 \mathrm{~V}$ for $24 \mathrm{~h}$ using a pulse-controller by Hoefer
(Scientific Instruments, San Francisco, CA). Initial pulse time was $2.4 \mathrm{~s}$ forward and $0.8 \mathrm{~s}$ reverse, with a ramp of $1.5 \mathrm{~s}$. After ethidium bromide staining and photography, the gel was subjected to UVL at $240 \mathrm{~nm}$ for $5 \mathrm{~min}$ and then soaked in denaturing solution $(0.4$ $N \mathrm{NaOH}, 1.5 \mathrm{M} \mathrm{NaCl}$ ) for $2 \mathrm{~h}$ before Southern transfer to Zetabind (AMF Cuno) for $48 \mathrm{~h}$ in denaturing solution. Size standards were Saccharomyces cerevisiae, strain AB792 chromosomes prepared according to Bellis et al. (1987) and concatenated $\lambda$ c1857 DNA prepared according to Waterbury and Lane (1987).

\section{RESULTS}

\section{Human Chromosome Complementing the INA Repair Defect in UV5}

Following fusion of human lymphocytes with UV5, a total of 21 independent colonies survived selection. Initial selection of most hybrids was in HAT + dcMMC; after 4 days, selection was continued in dcMMC alone. Biochemical, molecular, and cytogenetic analyses indicated that all surviving clones contained both human and Chinese hamster gene products, indicating that they were all interspecific somatic cell hybrids. Specific marker analyses (isozymes and DNA probes) identifying individual human chromosomes present in the hybrids were conducted, and the results are summarized in Table 1 . Since all hybrids are dcMMC resistant, all should have the human chromosome carrying the gene that complements the DNA repair deficiency. As can be seen from Table 1, chromosome 19 is the only chromosome that meets that expectation. The $\mathrm{X}$ chromosome is also present in a significantly higher number of hybrids than any other human chromosome except 19. That is expected as a consequence of the initial HAT selection, which would have been effective in causing emerging hybrids to retain human HPRT which is on the $\mathrm{X}$ chromosome.

To demonstrate that a gene on human chromosome 19 actually segregates with dcMMC or UVL resistance in hybrid cells and that the frequent presence of the $\mathrm{X}$ chromosome is not related to the repair function, UVL-resistant and -sensitive subclones were developed from hybrids 5 HL2, -9 , and -17 . They were studied for the presence or absence of human chromosomes 19, using glucose phosphate isomerase (GPI) as a marker, and $X$, using the glucose-6-phosphate dehydrogenase (G6PD) as a marker. The results are summarized in Table 2 and clearly indicate the concordant segregation of human chromosome 19 with UVL resistance, while the $\mathrm{X}$ chromosome was present independent of UVL. resistance.

The ability of hybrid subclones to survive UVI, relative to their human chromosome 19 content was determined quantitatively as survival curves. As can be seen in Fig. 1, sensitive hybrid subclones that had seg- 
TABLE 1

Human Chromosomes Present in Repair-Proficient Hybrids Made between Human Lymphocytes and UV5 Cells

\begin{tabular}{|c|c|c|c|c|c|c|c|c|c|c|c|c|c|c|c|c|c|c|c|c|c|c|c|}
\hline \multirow[b]{2}{*}{ Hybrid clone } & \multicolumn{23}{|c|}{ Human chromosome } \\
\hline & 1 & 2 & 3 & 4 & 5 & 6 & 7 & 8 & 9 & 10 & 11 & 12 & 13 & 14 & 15 & 16 & 17 & 18 & 19 & 20 & 21 & 22 & $\mathrm{X}$ \\
\hline $5 \mathrm{HL} 1$ & - & - & - & + & - & + & - & - & - & + & - & - & - & - & - & - & - & - & + & + & - & - & - \\
\hline $5 \mathrm{HL} 2$ & - & - & - & - & - & - & - & - & - & - & - & + & - & - & - & - & - & - & + & $\ldots$ & - & - & + \\
\hline $5 \mathrm{HL} 3$ & - & - & + & - & + & + & - & + & + & - & - & + & + & - & + & - & - & + & + & + & + & - & + \\
\hline $5 \mathrm{HI}, 4$ & - & - & - & + & + & - & - & - & + & - & - & $t$ & - & - & - & - & $t$ & + & + & - & $t$ & - & + \\
\hline 5HL.5 & - & - & + & + & + & + & - & - & + & - & + & + & - & + & + & - & - & - & + & + & $\cdots$ & + & + \\
\hline 5 HL 6 & + & - & + & + & + & + & - & - & + & + & + & + & - & + & + & - & - & + & + & + & - & + & + \\
\hline 5HL9 & - & - & - & - & - & - & - & - & - & - & - & - & -- & - & - & - & - & - & + & - & - & - & + \\
\hline 5 HL 10 & + & - & - & - & + & + & - & - & - & + & - & + & - & + & + & - & - & + & + & + & - & + & + \\
\hline $5 \mathrm{HL} 11$ & - & - & + & + & - & + & - & - & - & - & - & - & - & - & + & + & - & + & + & + & - & - & + \\
\hline $5 \mathrm{HL} 12$ & + & - & - & + & & + & - & + & + & + & $\cdots$ & + & + & + & + & - & - & + & + & - & + & $\cdots$ & + \\
\hline $5 \mathrm{HL} 13$ & - & - & + & + & + & - & - & + & + & - & - & + & + & + & + & - & - & + & + & + & + & + & + \\
\hline $5 \mathrm{HL}_{14}$ & - & + & + & - & + & - & + & + & + & - & + & - & - & + & - & - & - & + & + & + & - & + & + \\
\hline 5HL15 & - & - & - & + & + & + & + & - & - & + & + & - & - & + & + & - & - & + & + & - & + & + & + \\
\hline $5 \mathrm{HL} 16$ & - & - & - & + & - & - & - & + & + & + & - & - & + & + & - & - & - & - & + & - & - & + & + \\
\hline $5 \mathrm{HL} 17$ & + & - & - & - & - & - & - & - & - & - & - & + & - & - & - & - & - & - & + & - & - & - & + \\
\hline 5HL18 & - & - & - & - & - & + & + & + & - & + & + & $\cdots$ & + & + & - & - & - & + & + & - & + & - & + \\
\hline 5HL20 & - & - & - & - & + & + & - & + & + & - & - & - & + & + & - & - & - & - & + & -- & - & + & - \\
\hline $5 \mathrm{HL} 25$ & -. & - & - & - & + & + & - & + & - & - & - & + & - & - & - & - & - & - & + & - & - & - & + \\
\hline 5HL26 & + & - & + & - & + & + & - & + & + & - & + & + & + & - & + & - & - & + & + & + & - & + & + \\
\hline $5 \mathrm{HL} 27$ & + & - & - & + & + & + & + & - & + & - & + & + & - & + & + & - & - & + & + & + & + & + & + \\
\hline 5HL31 & - & - & + & - & - & + & - & + & + & - & + & + & - & - & + & - & - & + & + & + & - & - & + \\
\hline Percentage with & & & & & & & & & & & & & & & & & & & & & & & \\
\hline chromosome & 29 & 5 & 38 & 48 & 60 & 67 & 19 & 48 & 57 & 33 & 38 & 62 & 33 & 52 & 52 & 5 & 5 & 62 & 100 & 52 & 33 & 48 & 90 \\
\hline
\end{tabular}

regated human chromosome 19 produced survival curves that were similar to the curve seen with the parental UV5 mutant. Resistant subclones that retained human chromosome 19 showed greatly enhanced survival, approaching the level of resistance of the wildtype AA8 cells from which UV5 was derived. This in-

TABLE 2

Human Chromosome 19 and $X$ Retention in UVLResistant (R) and -Sensitive (S) Hybrid Subclones

\begin{tabular}{cccc} 
& & \multicolumn{2}{c}{ Chromosome } \\
\cline { 3 - 4 } Hybrid subclone & R or S & 19 & $\mathrm{X}$ \\
\hline 5HL2-1 & $\mathrm{S}$ & - & - \\
5HL2-2 & $\mathrm{S}$ & - & - \\
5HL2-3 & $\mathrm{R}$ & + & - \\
5HL2-4 & $\mathrm{R}$ & + & - \\
5HL9-2 & $\mathrm{S}$ & - & - \\
5HL9-3 & $\mathrm{S}$ & - & - \\
5HL9-4 & $\mathrm{R}$ & + & - \\
5HL9-5 & $\mathrm{R}$ & + & - \\
5HL17-1 & $\mathrm{S}$ & - & + \\
5HL17-2 & $\mathrm{S}$ & - & - \\
5HL17-3 & $\mathrm{R}$ & + & - \\
\hline
\end{tabular}

complete complementation may be due to the expression of and interference from other human genes on human chromosomes because full complementation was seen in UV5 cells transformed with the cloned ERCC2 gene (Weber et al., 1988).

Since hybrid line 5HL9 appeared to contain only human chromosomes 19 and X (Table 1) and its sub-

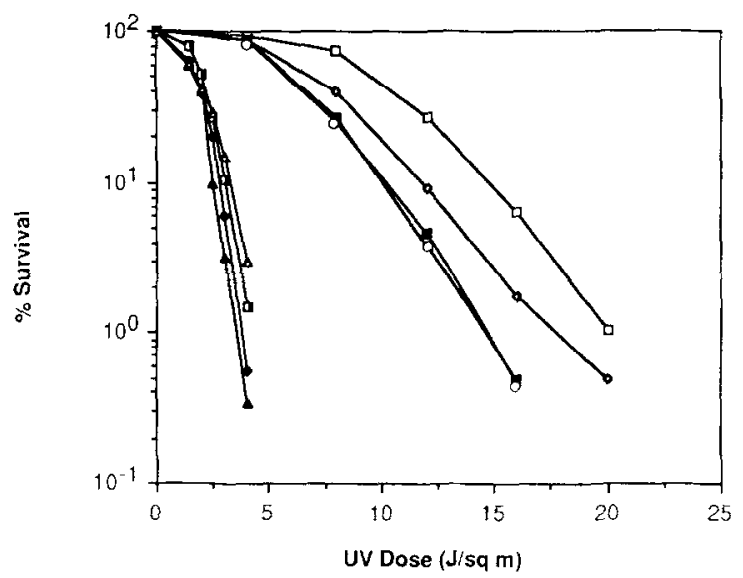

FIG. 1. Survival curves of colony-forming ability of UVL-irradiated parental lines and hybrid subclones. Symbols: wild-type CHO line AA8 ( $\square$ ); mutant UV5 ( ); hybrid subclones 5HL2-3 (O),

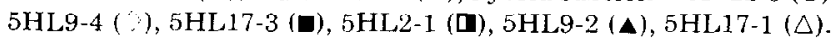


clone, 5HL9-4, appeared to have retained the 19 while losing the X, 5HL9-4 was examined cytogenetically using biotinylated total human DNA as probe to demonstrate the presence of human chromosome 19 as the only human genetic material present in the hybrid resolvable by this sensitive assay (Fig. 2).

The human gene that complements the repair defect in UV5 has been isolated in a cosmid vector (Weber et al., 1988). A 2.4-kb KpnI fragment containing the $3^{\prime}$ untranslated end of the gene was isolated and inserted into the KpnI site of vector pKSV-10 (Pharmacia, Piscataway, NJ). The resultant probe (pKER2) was hybridized to Southern blots of HindIII-cut DNA from a hybrid clone panel containing 33 independently derived human $\times$ CHO somatic cell hybrids containing different human chromosomes (previously described in Stallings et al., 1988). The ERCC2 probe segregated perfectly concordantly with human chromosome 19 , while all other chromosomes were discordant at levels of from 30 to $73 \%$.
All these analyses taken together allow us to assign to human chromosome 19 a gene that complements the DNA repair defect present in UV5. By the rules of nomenclature described in the Introduction, this gene has been designated Excision Repair Cross Complementing 2 (ERCC2).

\section{Regional Localization of ERCC2 among Chromosome 19 Markers}

We had shown that repair-proficient hybrids made between human cells and repair-deficient CHO lines often contained broken chromosomes such that varying portions of the human chromosome carrying the complementing gene were retained (Thompson et al., 1987). Those human segments often became integrated into the $\mathrm{CHO}$ genome, making the hybrids useful for establishing the order of genes in these chromosomal regions. Five such hybrids, three selected for ERCC1 (prefix 20XP in Table 3) and two for XRCC1 (prefix

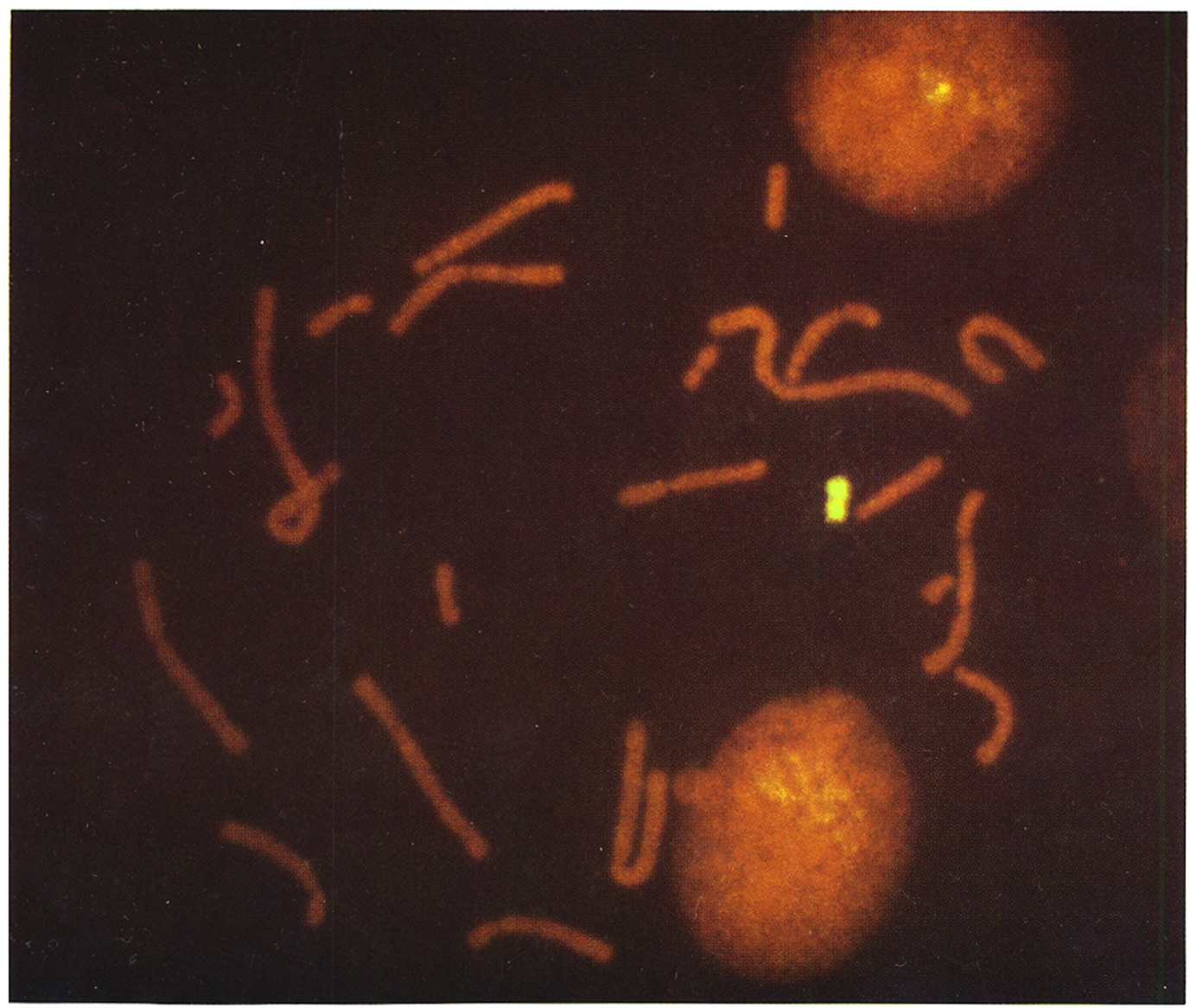

FIG. 2. Metaphase cell from the UVL-resistant hybrid line 5HL9-4 stained with fluorescein following in situ hybridization with biotinylated total human DNA. Only a single yellow-green fluorescing human element, which marker analysis confirms as being human chromosome 19 , is seen. This single chromosome was present in all 20 diploid hybrid cells examined. 
9HL), and probes for ERCC1, as well as a series of other markers, were used to determine the position of $E R C C 1$ relative to a series of markers on the long arm of chromosome 19 (Stallings et al., 1988). Here, those data are extended using the cloned probes for XRCC1 and $E R C C 2$ with those hybrids. The data are illustrated in Fig. 3 and summarized in Table 3.

The smallest segment of human chromosome 19 was retained in the three $20 \mathrm{XP}$ hybrids which were selected for the presence of $E R C C 1$. As previously reported (Stallings et al., 1988) those hybrids contained $E R C C 1$, $A P O C 2$, and CKMM. Of the markers tested here, the only additional gene in those three hybrids was ERCC2. The other hybrids, selected for XRCC1, retained larger pieces of human chromosome 19 , as indicated by the greater number of human chromosome 19 markers present. Taken together with the information that suggests $C G B$ and FTL are at the distal end, 19q13.3qtel (Worwood et al., 1985; Brook et al., 1986), of this series of markers, that GPI is at the proximal end, 19qcen-q13.1 (Kaneda et al., 1987), and that APOC2 is proximal to ERCC1 (Hulsebos et al., 1986), the data indicate a gene order on the long arm of chromosome 19 for the markers studied of

cen-GPI-(CYP2A,TGFB,XRCC1)-

[(APOC2-ERCC1)ERCC2,CKMM]-(CGB,FTL)-tel.

Therefore, of the three repair genes on the long arm of chromosome 19, XRCC1 appears to be the most proximal and in the same region of the chromosome as $C Y P 2 A$ and $T G F B$. The latter two markers have been identified by in situ hybridization as being at 19q13.1-q13.3 (Davis et al., 1985; Fujii et al., 1986). $E R C^{\prime} C 1$ and $E R C$ C'2 are more distal in a region marked by in situ hybridization studies with CKMM to 19q13.2-13.3 (Nigro et al., 1987), yet physically distinguishable from each other as indicated by their presence on two different macrorestriction fragments, 75 and $580 \mathrm{~kb}$, respectively, following $M l u \mathrm{I}$ digestion of both HeLa and 20XP3542-1-4 cell DNA (Fig. 4).

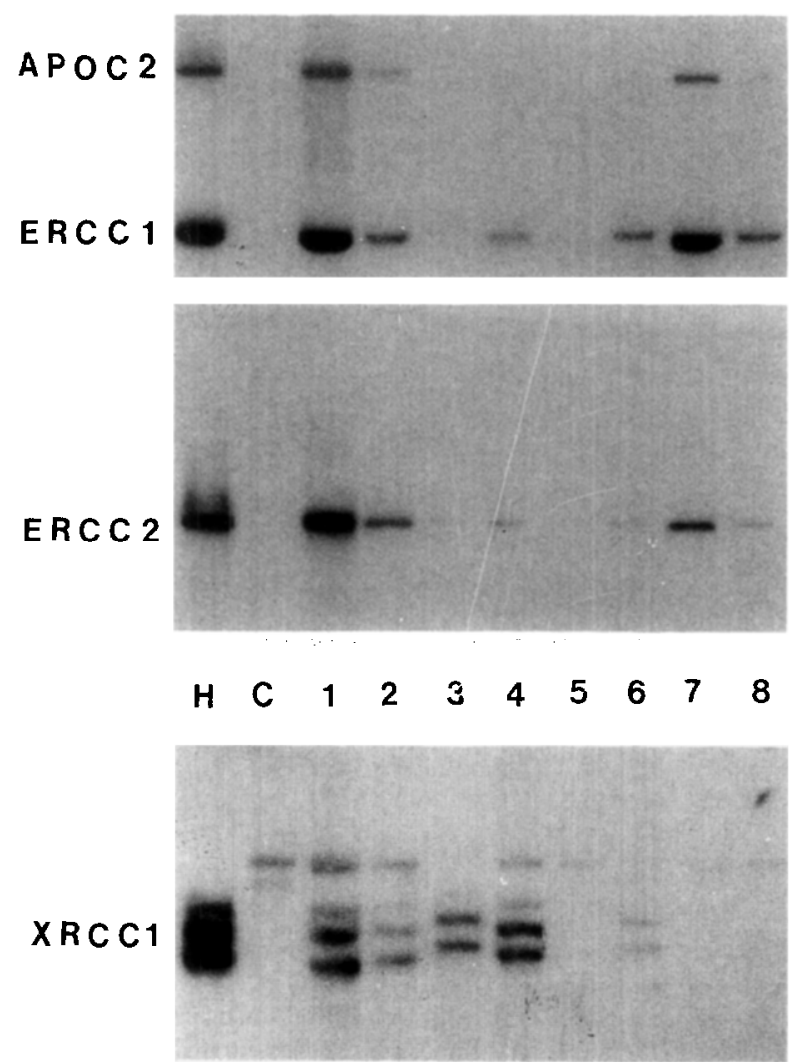

FIG. 3. Three panels represent the same Southern blot filter hybridized with probes for APOC2 and ERCC1 (top), ERCC2 (middle), and XRCC1 (bottom). Channels contain HindIII-digested DNAs from Hela (H) and CHO (C) cell controls, seven hybrids containing chromosome 19 of varying lengths (1-4 and 6-8), and one hybrid (5) not having a 19. Two hybrids (20XP2992-1 and 20XP04352 , numbered here $\mathbf{7}$ and $\mathbf{8}$, respectively) selected for $E R C C 1$ retain human $A P O C 2, E R C C 1$, and $E R C C 2$ while not retaining XRCC1.

Chromosomal Assignment of the Three Human

Chromosome 19 DNA Repair Genes

in the Chinese Hamster

The chromosomal assignment of ERCC2 now puts three of the five mapped human DNA repair genes complementing different mutations in $\mathrm{CHO}$ cells on

TABLE 3

Hybridization of Human Repair Gene Probes Relative to the Presence of Chromosome 19 q-arm Markers among Hybrids with a Disrupted $19^{a}$

\begin{tabular}{|c|c|c|c|c|c|c|c|c|c|c|}
\hline \multirow[b]{2}{*}{ Hybrid } & \multicolumn{10}{|c|}{ Markers and repair genes present $(+)$ or absent $(-)$} \\
\hline & GPI & CYP2A & TGFB & $\mathrm{XRCC} 1$ & $\mathrm{APOC} 2$ & CKMM & FRCC? & FRCCA1 & CGB & $\mathrm{FTL}$ \\
\hline 9HL5 & + & + & + & + & + & + & + & + & - & - \\
\hline $9 \mathrm{HL} 1.1$ & & $t$ & I & 1 & $t$ & + & + & + & - & - \\
\hline 20XPO435-2 & - & - & - & - & + & + & + & + & - & - \\
\hline 20XP2992-1 & - & - & - & - & + & + & + & + & - & - \\
\hline $20 \times P 3542-1-4$ & - & - & - & - & + & + & + & + & - & - \\
\hline
\end{tabular}

${ }^{a}$ Nonrepair gene markers were previously characterized in this series of hybrids $(32)$. 


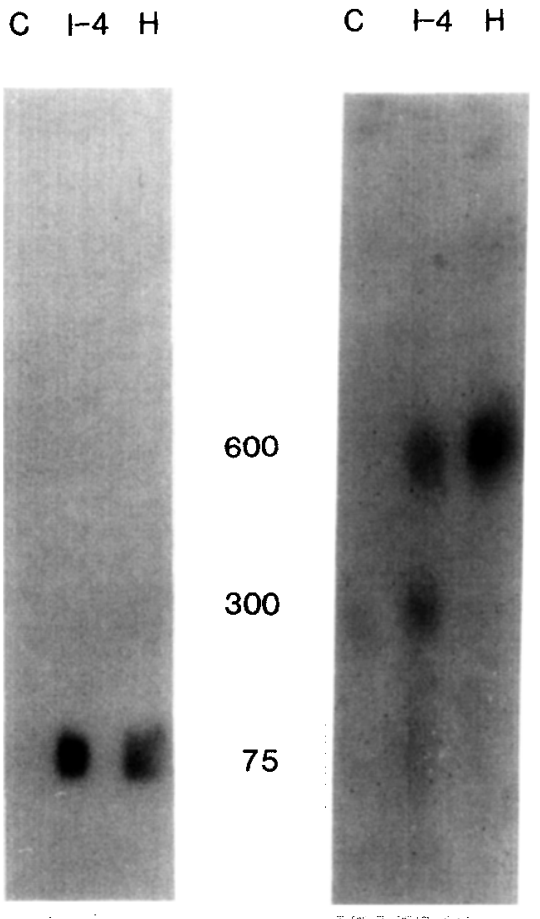

FIG. 4. Southern blot filters following field-inversion electrophoresis of MluI-digested DNA from CHO (C), hybrid 20XP35421-4 (1-4), and HeLa (H) cells hybridized with probe for ERCC1 (left) and ERCC2 (right). ERCC1 hybridizes to a $75-\mathrm{kb} M l u \mathrm{I}$ fragment, while ERCC2 is on a fragment of approximately $600 \mathrm{~kb}$. The ERCC2 cDNA probe also detects a $300-\mathrm{kb}$ Chinese hamster fragment present in both the $\mathrm{CHO}$ cell and the hybrid line.

the same human chromosome. We then asked whether the homologs of these three genes were conserved on the same syntenic group in the Chinese hamster; and if so, was there something about that chromosome in CHO cells that contributed to the isolation of a high frequency of recessive mutations at loci on that chromosome, which could explain the seemingly disproportionate number of repair genes assigned to the human chromosome 19.

In order to investigate this question, we used a panel of somatic cell hybrids made between euploid Chinese hamster cells and the mouse cell line LMTK Cl1D and which was informative for Chinese hamster chromosomes. All hybrids were characterized cytogenetically as well as with the known biochemical markers (Siciliano et al., 1985) for the presence of hamster chromosomes. cDNA probes for all three repair genes crosshybridized with both mouse and Chinese hamster genomic DNA and detected Chinese hamster-specific HindIII restriction fragments. The presence or absence of the different Chinese hamster chromosomes and the sequences that hybridized to the three different human repair gene probes are summarized in Table 4. As tabulated, all three genes segregated perfectly concordantly with hamster chromosome 9 , while the other chromosomes had levels of discordance ranging from 15 to $62 \%$. Therefore, we conclude that the three
Chinese hamster genes homologous to ERCC1, ERCC2, and $\mathrm{XRCCl}$ are in an evolutionarily conserved linkage group on Chinese hamster chromosome 9. This observation and its consequences with respect to mutagenesis in CHO cells are discussed below.

\section{DISCUSSION}

\section{Is the Third Repair Gene on Chromosome 19 Different from the Other Two?}

There appears to be little question, from the multiple approaches and data presented here, that a gene on human chromosome 19 complements the DNA repair deficiency in the CHO mutant UV5, which is a member of rodent complementation group 2. Furthermore, this assignment has been independently supported (Mohrenweiser et al., 1989) by another method-in situ hybridization with a biotinylated ERCC2 cosmid clone to human metaphase chromosomes. Since two other genes that complement DNA repair deficiencies in CHO cells have already been assigned to chromosome 19, one could ask for assurance that ERCC2 represents a physically distinct genetic entity.

Differences among the three CHO mutant groups (with respect to complementation groups into which they fall, agents to which they are hypersensitive, and the biological manifestations and biochemical bases of their defects--Thompson, 1985) are certainly compelling reasons to consider the three human genes that complement them to be distinct. The findings that cosmid clones of each nucleotide excision repair gene correct only the corresponding rodent complementation group and the observation that there are no clear similarities in the restriction enzyme site patterns of ERCC1 and ERCC2 cosmid clones are also consistent with the physical uniqueness of these two genes (van Duin et al., 1988; Weber et al., 1988). In this report we provide additional evidence for the distinct physical uniqueness of all three genes by our localization of $X R C C 1$ to a more proximal position on chromosome 19 than ERCC1 and ERCC2 and by demonstrating the presence of the latter two genes on different MluI macrorestriction fragments.

\section{Consequences of Human 19-Hamster 9 Homology for Our Understanding of Repair Gene Distribution and Number}

Conservation of the syntenic relationship of genes on human chromosome 19 has been observed to be fairly phylogenetically extensive. At least 10 long-arm markers of the human 19 (GPI, PEPD, etc.) have been shown to be linked on the mouse 7 (Lalley et al., 1987). GPI and PEPD have also been shown to be on the same chromosome, not only in numerous mammalian species but also in evolutionary diverse forms such as amphibians (D. A. Wright et al., 1983) and two different 
TABLE 4

Chinese Hamster Chromosomal Content in, and Hybridization of Repair Gene cDNAs to, Hybrids Segregating Chinese Hamster Chromosomes

\begin{tabular}{|c|c|c|c|c|c|c|c|c|c|c|c|c|c|c|}
\hline \multirow{2}{*}{$\begin{array}{l}\text { Hybrid } \\
\text { clone }\end{array}$} & \multicolumn{11}{|c|}{ Chinese hamster chromosome } & \multicolumn{3}{|c|}{ Repair gene cDNAs } \\
\hline & 1 & 2 & 3 & 4 & 5 & 6 & 7 & 8 & 9 & 10 & $\mathrm{X}$ & ERCC1 & ERCC2 & $\mathrm{XRCCl}$ \\
\hline $\mathrm{C} 2 / \mathrm{B} 1$ & - & -- & + & + & - & + & + & + & + & + & + & + & + & + \\
\hline $\mathrm{C} 2 / \mathrm{B} 2$ & - & - & + & + & + & + & + & - & + & + & + & + & + & + \\
\hline $\mathrm{DA} 1 / \mathrm{A} 3$ & + & + & - & + & + & + & + & + & + & + & + & + & + & + \\
\hline $\mathrm{DAl} / \mathrm{M} 1 \mathrm{~A} 1$ & + & + & - & + & + & + & + & + & + & + & - & + & + & + \\
\hline $\mathrm{DA} 2 / \mathrm{A} 2$ & + & + & - & + & + & + & + & + & + & + & + & + & + & + \\
\hline $\mathrm{D} 3 / 3 / \mathrm{B} 1$ & + & + & + & + & + & + & - & + & + & + & + & + & + & + \\
\hline $\mathrm{D} 4 / 1$ & + & + & + & + & + & - & + & + & - & + & $t$ & & & - \\
\hline $\mathrm{D} 4 / 9$ & + & + & + & + & - & - & + & + & - & + & + & - & - & $\ldots$ \\
\hline D19/8 & + & + & + & + & + & + & + & + & - & + & + & - & - & $\ldots$ \\
\hline D $19 / 11$ & + & + & - & + & + & + & + & + & + & + & + & + & + & + \\
\hline $\mathrm{E} 3 / \mathrm{D}$ & + & - & + & + & + & + & + & + & - & - & - & - & $\ldots$ & - \\
\hline $\mathrm{E} 9 / \mathrm{D} 3 / 4$ & - & - & + & + & + & + & + & $t$ & + & + & - & + & + & + \\
\hline E12/D1 & + & - & + & $t$ & + & + & $t$ & + & + & + & $t$ & + & + & + \\
\hline $\begin{array}{l}\text { Percentage } \\
\operatorname{disc}^{a}\end{array}$ & 54 & 54 & 62 & 31 & 31 & 15 & 38 & 38 & 0 & 25 & 42 & & & \\
\hline
\end{tabular}

a The percentage of hybrids that had the chromosome but not the repair gene markers plus the percentage that did not have the chromosome but had the repair gene markers.

families of teleost fish (J. E. Wright et al., 1983; Morizot, 1986). The cDNA clones for the repair genes are now being studied in the fish system, where they have been found to hybridize and detect restriction fragment length polymorphisms (RFLPs) in crosses informative for linkage (Morizot, personal communication). As more genes are identified within this conserved linkage group and its boundaries are understood, this region may become attractive for studying the forces responsible for such conservation.

In this report we have extended the region of the human 19 that we see conserved in the hamster. Our original identification of the homology between regions of the human 19 and hamster 9 came from gene mapping studies which identified the hamster 9 as the location of GPI and PEPD (Siciliano et al., 1983). Here, by detecting the repair genes on the hamster 9 , we extend the conserved section of the human 19 from the proximal long arm in the region of the centromere where PEPD is located (Friedrich et al., 1987) to 19q13.2-13.3 where the two most distal repair genes are located-a physical distance in humans of at least $20 \mathrm{Mb}$.

One of the more significant aspects of the presence of the repair genes on the hamster chromosome 9 relates to the cytogenetic observations of Deaven and Peterson (1973) indicating that there is only a single chromosome 9 in CHO cells. We (Siciliano et al., 1983) determined that genes on the hamster chromosome 9 were present in CHO cells in a physically haploid state by two methods: (1) observing concordant segregation of $G P I$ and $P E P D$ with the single chromosome 9 from somatic cell hybrids made between CHO cells and mouse LMTK Cl1D cells from which CHO chromosomes underwent segregation, and (2) observing that electrophoretic shift mutations induced at those loci in CHO cells resulted in hemizygous rather than heterozygous patterns.

The presence of the repair genes on a hemizygous chromosome in CHO cells would appear to account for the relative ease with which recessive mutations at these loci were uncovered in the cells (Thompson et al., 1980, 1981). In the original mutagenesis experiments the mutant isolates in UVL complementation groups 1 and 2 comprised $94 \%$ of all UVL repair mutants recovered among 6 complementation groups ('Thompson, 1985; Busch et al., 1989). Physical hemizygosity in CHO cells appears to be limited to no more than $25 \%$ of the genome, a significant portion of which can be attributed to a single $\mathrm{X}$ chromosome, the hemizygous 9 , and a large deletion in the long arm of chromosome 2 as determined by cytogenetic studies (Deaven and Peterson, 1973; Worton et al., 1977). This estimate of the extent of hemizygosity is consistent with the frequency of more than 40 randomly selected $\mathrm{CHO}$ isozyme loci which produce hemizygous rather than heterozygous electrophoretic shift mutations ( $\mathrm{Si}$ ciliano et al., 1978, 1986b). Consequently, there is a bias for the isolation of recessive DNA repair mutations at loci on the hamster chromosome 9 in CHO cells. Therefore, due to the established homology between human chromosome 19 and hamster chromosome 9, genes on human chromosome 19 that complement mutations on the hamster 9 would be more readily iden- 
tified than human genes located on chromosomes homologous to nonhemizygous regions of the rodent genome.

The demonstrated bias for the apparent clustering of DNA repair genes on human chromosome 19 suggests that there may be many other DNA repair genes in the human genome. Since the mapping and cloning of the chromosome 19 repair genes were made possible by the ready isolation of rodent mutations in the homologous loci, the search for additional rodent lines that are hemizygous for other areas of the genome would seem important. Such lines might produce new spectra of mutants appropriate for identifying and cloning heretofore unknown human DNA repair genes.

\section{ACKNOWLEDGMENTS}

We thank the following individuals for enabling us to use probes for the following chromosome genes in this study: $C 3$ and $C Y P 2 A$, Robert Williamson at Saint Mary's Hospital (London); APOC2, Larry Chan at Baylor College of Medicine (Houston); CKMM. Ben Perryman at Baylor College of Medicine (Houston); CGB, Mary Riser at the Baylor College of Medicine (Houston); TGFB, Rik Derynck at Genentech, Inc. (So. San Francisco); and $F T L$, James Drysdale at Tufts University (Boston). This work was supported in part by NIH Grants CA34936, CA04484, and CA09299 and awards from Muscular Dystrophy Association, the Piton Foundation, and Kenneth D. Muller to the University of Texas M. D. Anderson Cancer Center; and performed in part under the auspicis of the U.S. Department of Energy by the Lawrence Livermore National Laboratory under Contract W-7404-ENG48.

\section{REFERENCES}

1. Bellis, M., Pages, M., AND RoIzes, G. (1987). A simple and rapid method for preparing yeast chromosomes for pulse field gel electrophoresis. Nucleic Acids Res. 15: 6749.

2. BRook, J. D., Shaw, D. J., Thomas, N. S. T., Mrrenith, A. L., COWELL, J., AND HARPER, P. S. (1986). Mapping genetic markers on human chromosome 19 using subchromosomal fragments in somatic cell hybrids. Cylogenet. Cell Genet. 41: 30-37.

3. Busch, D., Thompson, L., Greiner, C., Lewis, K., ANd Adair, G. (1989). Summary of complementation groups of UV-sensitive CHO cell mutants isolated by large scale screening. Submitted for publication.

4. Carle, G., Frank, M., And Olson, M. V. (1986). Electrophoretic separation of large DNA molecules by periodic inversion of the electric field. Science 232: 65-68.

5. Collins, A., AND Johnson, R. T. (1987). DNA repair mutants of higher eukaryotes. In "Molecular Biolugy of DNA Repair" (A. Collins, R. T. Johnson, and R. M. Boyle, Eds.), J. Cell Sci. Suppl. 6: 97-110.

6. Davis, M. B., West, L. F., Phillips, I. R., And Shephard, E. A. (1985). Chromosome location of CYP1 by in situ hybridization. Cytogenet. Cell Genet. 10: 613.

7. Deaven, L. L., and Petersen, D. F. (1973). The chromosomes of $\mathrm{CHO}$, an aneuploid Chinese hamster cell line: G-band, Cband and autoradiographic analysis. Chromosoma 41: 129-144.

8. Fiddes, J. C., AND GoodMAN, H. M. (1980). The cDNA for the beta-subunit of human chorionic gonadotropin suggests evolution of a gene by readthrough into the $3^{\prime}$-untranslated region. Nature (London) 286: 684-687.
9. Friedrich, U., Brunner, H., SmeEts, D., Lamberman, E., AND ROPERS, H.-H. (1987). Three-point linkage analysis employing $\mathrm{C} 3$ and $19 \mathrm{cen}$ markers assigns the myotonic dystrophy gene to 19q. Hum. Genet. 75: 291-293.

10. Fuji, D., Brissenden, J. E., Derynck, R., AND Franke, U. (1986). Transforming growth factor beta gene maps to human chromosome 19 long arm and to mouse chromosome 7. Somat. Cell Mol. Genet. 12: 281-288.

11. Hickson, I. D., AND HaRRIS, A. L. (1988). Mammalian DNA repair-use of mutants hypersensitive to cytotoxic agents. Trends Genet. 4: 101-106.

12. Hoy, C. A., Salazar, E. P., and Thompson, L. H. (1984). Rapid detection of DNA-damaging agents using repair-deficient CHO cells. Mutat. Res. 130: 321-332.

13. Hulsebos, T., Wieringa, B., Hochstenbach, R., Smefts, D., Schepens, J., Oerlemans, F., Zimmer, J., AND Ropers, H. H. (1986). Toward early diagnosis of myotonic dystrophy: Construction and characterization of a somatic cell hybrid with a single human der(19) chromosome. Cytogenet. Cell Genet. 43: $47-56$.

14. Jackson, C. L., Bruns, G. A. P., And Breslow, J. L. (1984). Isolation and sequence of a human apolipoprotein CII clone and its use to isolate and map to human chromosome 19 the gene for apolipoprotein CII. Proc. Natl. Acad. Sci. USA 81: 2945-2949.

15. Jones, N. J., Cox, R., AND ThaCkeR, J. (1988). Six complementation groups for ionizing-radiation sensitivity in Chinese hamster cells. Mutat. Res. 193: 139-114.

16. Kaneda, Y., Hayes, H., UChida, T., Yoshida, M. C., AND OKADA, Y. (1987). Regional assignment of five genes on human chromosome 19. Chromosoma 95: 8-12.

17. Lalley, P. A., O'Brien, S. J., Creal-Goldberg, N., Davisson, M. T., Roderick, T. H., Echard, G., WOMACK, J. E., GRAVES, J. M., DoolitTle, D. P., AND GUid, J. N. (1987). Report of the committee on comparative mapping. Cytogenet. Cell Genet. 46: $367-389$.

18. Maniatis, T., FRiTsCh, E. F., AND SAmbrook, J. (1982). "Molecular Cloning: A Laboratory Manual," Cold Spring IIarbor Laboratory, Cold Spring Harbor, NY.

19. Mohrenweiser, H. W., Carrano, A. V., Fertitta, A., Perry, B., Thompson, L. H., Tucker, J. D., AND Weber, C. A. (1989). Refined mapping of the three DNA repair genes, ERCC1, ERCC2, and XRCC1, on human chromosome 19. Cytogenet. Cell Genet., in press.

20. MoRIzoT, D. C. (1986). Linkage maps of biochemical loci in the fish genera Poeciliopsis and Xiphophorus $(2 \mathrm{~N}=48)$. In "Genetic Maps" (S. J. O'Brien, Ed.), pp. 414-415, Cold Spring Harbor Laboratory, Cold Spring Harbor, NY.

21. Nigro, J. M., Schweinfest, C. W., Rajkovic, A., Pavlovic, J., Jamal, S., Dottin, R. P., HaRT, J. T., Kamarck, M. E., RAE, P. M. M., CARTY, M. D., AND MAR'TIN-DELEON, P. (1987). cDNA cloning and mapping of the human creatine kinase $M$ gene to 19q13. Amer. J. Hum. Genet. 40: 115-125.

22. Perryman, M. B., Kerner, S. A., Bohlmeyer, T. J., AND ROBERTS, R. (1986). Isolation and sequence analysis of a fulllength cDNA for human $\mathrm{M}$ creatine kinase. Biochem. Biophys. Res. Commun. 140: 981-989.

23. Phillips, I. R., Shephard, E. A., Ashworth, A., AND Rabin, B. R. (1985). Isolation and sequence of a human cytochrome P-450 cDNA clone. Proc. Natl. Acad. Sci. USA 82: 983-987.

24. Pinkel, D., Straume, T., ANd Gray, J. W. (1986). Cytogenetic analysis using quantitative, high-sensitivity, fluorescence hybridization. Proc. Natl. Acad. Sci. USA 83: 2934-2938.

25. Siciliano, M. J., Siciliano, J., ANd Humphrey, R. M. (1978). Electrophoretic shift mutants in Chinese hamster ovary cells: 
Evidence for genetic diploidy. Proc. Natl. Acad. Sci. USA 75: 1919-1923.

26. Siclliano, M. J., Stallings, R. L., Adair, G. M., Humphrey, R. M., AND Siciliano, J. (1983). Provisional assignment of TPI, GPI, and PEPD to Chinese hamster autosomes 8 and 9: $\mathrm{A}$ cytogenetic basis for functional haploidy of an autosomal linkage group in CHO cells. Cytogenet. Cell Genet. 35: 15-20.

27. Siciliano, M. J., STAllings, K. L., AND AdaiR, G. M. (1985). The genetic map of the Chinese hamster and the genetic consequences of chromosomal rearrangements in $\mathrm{CHO}$ cells. In "Molecular Cell Genetics" (M. M. Gottesman, Ed.), pp. 95138, Wiley, New York.

28. Siciliano, M. J., Carrano, A. V., and Thompson, L. H. (1986a). Assignment of a human DNA-repair gene associated with sister-chromatid exchange to chromosome 19. Mutat. Res. 174: 303-308.

29. Siciliano, M. J., Stallings, R. L., Humphrey, R. M., AND ADAIR, G. M. (1986b). Mutation in somatic cells as determined by electrophoretic analysis of mutagen-exposed Chinese hamster overy cells. In "Chemical Mutagens" (F. J. de Serres, Ed.), Vol. 10, pp. 509-531, Plenum, New York.

30. Siciliano, M. J., AND WHITE, B. F. (1987). Isozyme identification of chromosomes in interspecific somatic cell hybrids. In “Methods in Enzymology" (M. M. Gottesman, Ed.), Vol. 151, pp. 169-193, Academic Press, New York.

31. SMiTH, H. O. (1980). Recovery of DNA from gels. In "Methods in Enzymology" (L. Grossman, and K. Moldave, Eds.), Vol. 65, pp. 371-380, Academic Press, New York.

32. Stallings, R. L., Olson, E., Strauss, A. W., Thompson, L. H., BACHINSKI, L., AND SiCILIANO, M. J. (1988). Human creatine kinase genes on chromosomes 15 and 19 and the proximity of the gene for the muscle form to genes linked to myotonic dystropy. Amer. I. Hum. Genet. 43: 144-151.

33. Thompson, L. H. (1985). DNA repair mutants. In "Molecular Cell Genetics" (M. M. Gottesman, Ed.), pp. 641-668, Wiley, New York.

34. ThOMPSON, L., AND Bootsma, D. (1988). Designation of mammalian complementation groups and repair genes. In "Mechanisms and Consequences of DNA Damage Processing" (E. C. Friedberg, and P. C. Hanawalt, Eds.), U.C. Symposia on Molecular and Cellular Biology, New Series Vol. 83, p. 279, A. R. Liss, New York.

35. Thompson, L. H., Rubin, J., Cleaver, J. E., and Brookman, K. (1980). A screening method for isolating DNA repair-deficient mutants of CHO cells. Somat. Cell Genet. 6: 391-405.

36. Thompson, L. H., BusCh, D. B., BROOKMAN, K., MOONEY, C. L., AND GLASER, D. A. (1981). Genetic diversity of UV-sensitive DNA repair mutants of Chinese hamster ovary cells. Proc. Natl. Acad. Sci. USA 78: 3734-3737.

37. Thompson, L. H., Mooney, C. L., Burkhart-Schultz, K., Carrano, A. V., AND Siclliano, M. J. (1985). Correction of a nucleotide-excision repair mutation by human chromosome 19 in human-hamster hybrid cells. Somat. Cell Mol. Genet. 11: $87-92$.

38. Thompson, L. H., Carrano, A. V., Sato, K., Salazar, E. P., White, B. F., Stewart, S. A., MinkLer, J. L., AND Siciliano,
M. J. (1987). Identification of nucleotide-excision-repair genes on human chromosomes 2 and 13 by functional complementation in hamster-human hybrids. Somat. Cell Mol. Genet. 13: 539-551.

39. ThOMSPON, L. H., SHIOMt, T., SAlazar, E. P., AND STFWAR'T, S. A. (1988). An eighth complementation group of rodent cells hypersensitive to ultraviolet radiation. Somat. Cell Mol. Genet. 14: $605-612$.

40. Van Duin, M., DE WIT, J., OdiJK, H., Westerveld, A., Yasui, A., KoKen, M. H. M., HoeiJMaKers, J. H. J., AND Bootsma, D. (1986). Molecular characterization of the human excision repair gene ERCC-1: cDNA cloning and amino acid homology with yeast DNA repair gene RAD10. Cell 44: 913-923.

41. van Duin, M., Janssen, J. H., DE WiT, J., Hoeijmakers, J. H. J., THOMPSON, L. H., BOOTSMA, D., AND Westerveld, A. (1988). Transfection of the cloned human excision repair gene $E R C C-1$ to UV-sensitive CHO mutants only corrects the repair defect in complementation group 2 mutants. Mutat. Res. 193: 123-130.

42. Waterbury, P. G., AND LANE, M. J. (1987). Generation of lambda plug concatemers for use as pulsed field electrophoresis size markers. Nucleic Acids Res. 15: 3930.

43. Weber, C. A., Salazar, E. P., StewarT, S. A., ANd Thompson, L. H. (1988). Molecular cloning and biological characterization of a human gene, ERCC2, that corrects the nucleotide excision repair defect in CHO UV5 cells. Mol. Cell. Biol. 8: 1137-1146.

44. Westerveld, A., Hoeidmakers, J. H. L., van Duin, M., De Wit, D., OdiJK, H., PAstink, A., Wood, R. D., And Bootsma, D. (1984). Molecular cloning of a human DNA repair gene. Nature (London) 310: 425-429.

45. Worton, R., DuFf, C., AND Flintoff, W. (1977). Chromosome stability in CHO cells. Somat. Cell Genet. 3: 27-46.

46. Worwood, M. J., Brook, J. D., CRAGG, S. J., Hellkuhl, B., Jones, B. M., PERERa, P., Roberts, S. H., AND Shaw, D. J. (1985). Assignment of human ferritin genes to chromosomes 14 and 19q13.3-19qter. Hum. Genet. 69: 371-374.

47. Wright, D. A., Richards, C. M., Frost, J. S., Camozzi, A. M., AND KUNZ, R. J. (1983). Gene mapping in amphibians. In "Isozymes: Current Topics in Biological and Medical Research" (M. C. Rattazzi, J. G. Scandalios, and G. S. Whitt, Eds.), Vol. 10, pp. 287-311, A. R. Liss, New York.

48. WRight, J. E., Johnson, K., Hollister, A., AND MAY, B. (1983). Meiotic models to explain classical linkage, pseudolinkage, and chromosome pairing in tetraploid derivative salmonid genomes. In "Isozymes: Current Topics in Biological and Medical Research" (M. C. Rattazzi, J. G. Scandalios, and G. S. Whitt, Eds.), Vol. 10, pp. 239-260, A. R. Liss, New York.

49. Yamanka, I. H., BartietT, R. J., Ross, D. A., Fey, H. G., Ledbetter, D. H., Bruns, G., Pericak-Vance, M. A., Herbstreith, M. H., AND Roses, A. D. (1985). Localization of cloned unique DNA to three different regions of chromosome 19: Screen for linkage probes for myotonic dystrophy. $J$. Neurogenet. 2: 403-412.

50. ZDZIENICKA, M., AND SIMONS, J. W. I. M. (1987). Mutagensensitive cell lines are obtained with a high frequency in V79 Chinese hamster cells. Mutat. Res. 178: 235-244. 